DOI: https://doi.org/10.18485/philologia.2020.18.18.8 UDC: 821.111-31.09 0rwell G.

\title{
AESTHETIC LEGITIMACY FOR THE DYSTOPIAN ENVIRONMENT IN ORWELL'S NINETEEN EIGHTY-FOUR
}

\author{
ADRIAN-FLORIN BUȘU ${ }^{1}$ \\ University of Craiova \\ Craiova, Romania
}

Roman Džordža Orvela „Hiljadu devetsto osamdeset četvrta” (1949), opisujući totalitarno društvo i totalitarni režim na dosad neuobičajeni način, ostavio je veliki trag u književnosti i snažan uticaj na čitalačku publiku. Publika se zainteresovala za temu pojedinca pod nadzorom države, kao i za nove književne forme i za sve one druge promene koje je postmodernizam sobom doneo. Džordž Orvel je najpodrobnijim opisom distopijskog okruženja nadmašio fenomen konačnog ljudskog propadanja zbog nerazborite okrutnosti. Orvelov izmišljeni svet estetski je opravdan, iako su neki kritičari primetili da je u njegovom stvaralaštvu prisutan samo jedan pripovedački glas. Upotrebljavajući parabolu, autor je stvorio iracionalni, izmišljeni svet po uzoru na Kafku, ali paradoks je da ga je publika strastveno čitala zbog njegovog okrutnog realizma i događaja koji će se čitaocima urezati u sećanje. Roman ne uspeva da dostigne estetski apsolut i ne prikazuje izuzetno konstruktivnu radnju, već potvrđuje veliki ljudski problem i egzistencijalnu napetost, stvarajući utisak iscrpnog ispitivanja čovečanstva. Složenost Orvelovog izražavanja je metafora za iracionalni svet, a njegova knjiga je sredstvo pomoću kojeg se na najtransparentniji način sagledava mehanizam terora.

Ključne reči: distopijsko okruženje, mentalitet, ljudska degradacija, napetost, mehanizam terora.

\section{DYSTOPIAN SOCIETY UNDER THE ASSAULT OF TERROR}

In his Nineteen Eighty-Four, George Orwell depicted the most accurate image of a dystopian environment, surpassing the phenomenon of ultimate human degradation under the assault of irrational cruelty. A dystopia that imagines extreme developments

1 Kontakt podaci (Email): adibusu2002@yahoo.com 
of totalitarianism is Aldous Huxley's novel Brave New World, published in 1932, which led to the criticism of the similitude of vision between the two authors. Unlike Huxley's book, Nineteen Eighty-Four seems to concentrate the whole dismay of a world that was affected by two world wars in just half of a century. The psychological conditions in which this novel was conceived decisively influenced the writer, who had previously participated in the Civil War in Spain. His creative mind went all the way to the boundary of the social abyss in order to be able to contemplate and reveal to the readers the abyss of the human being and the darkness of the soul. Orwell demonstrates through this novel that literature lends credit to narrative formulas, to compositional structures, to formal fantasies, for, as Eugen Negrici claims, "form creates the background and not the other way around" (Negrici 2002: 335). Orwell's fictional world has aesthetic legitimacy, even though there are critics that have pointed out the presence of a single narrative voice. The author created a parable developed with Kafkian means, an irrational fictional world, but which is, paradoxically, passionately read for its cruel realism and for its memorable scenes. The novel does not touch the aesthetic absolute, it does not illustrate an exceptional constructive performance, but does confirm a major human problem and an existential tension, creating the impression of thorough analysis of humanity. The difficulty of writing is the metaphor of the irrationality of the world and the book is a transparent product, through which we follow the mechanism of terror in full operation.

Oceania, the space imagined by Orwell, similar to Faulkner's imaginary location - Yoknapathawpha, is aesthetically validated. Famous dictionaries, such as The Grand Larousse or The British Encyclopedia, illustrate the author's importance. The pertinence of judgments pronounced by scholars on this strange dystopia, the repetitive quotes that seem to be permanent, the frequent use of the terms Big Brother, Proli, Double Thought, the Thought Police (Thinkpol), and the adjective Orwellian, the journalistic, essayistic and academic criticism, plus the assent from the trained public, particularly the young, highlight the aesthetic value of this book.

\section{LITERARY VERSUS POLITICAL INTENT}

Critical emphasis in both older and recent studies of the fact that the reader receives political information from this fictional world is correct. "The marked political intent" (Grigore 2016: 32), visible in all Orwell's novels, which Rodica Grigore speaks about, explains the genesis of the work rather than its content. The opinion advanced by Antoine Compagnon, according to which "the only intention that matters to an author is to create literature" (Compagnon 2000: 82), is worth mentioning, as the reader deduces that it seems reasonable to relate the intention to the creative project. The validity of this theory is confirmed by Eugen Negrici, who stated that in the space of authentic literature, the writer understands that the characters become valid through the illusion of art (Negrici 2002: 16).

Orwell's novel is a political novel, but it is equally a novel about love and social problems. If it had been only a political novel, in which the theism was unavoidable, as the effort of unmasking and revealing the truth is a condition of the genre, the creation would not have had the same literary destiny. 
Nineteen Eighty-Four comprises the description of a poor people's society, a Great Britain after a hypothetical nuclear war between the East and the West, which would have occurred in the mid-twentieth century. The regime established in 0ceania, Soceng (the English Socialism), is of Stalinist inspiration with Nazi nuances. It is basically a mixture of two antagonistic political systems.

In pages containing a maximum economy of stylistic means, but of great expressivity, the author creates a terrifying atmosphere: people live from one day to the next, with rationalized food, in buildings with degraded walls. Poverty is obvious everywhere. On the immense posters present in all the civil buildings and in the institutions, the portrait of the dictator is omnipresent, a person who maintains the myth of control, below which is written: "Big Brother is watching you". In all the rooms of the apartments are tele-screens that continuously transmit and receive images and sounds with a special feature: the volume can be turned down, but not switched off completely. Police patrols supervise the population by flying in helicopters at low altitude, descending to the level of the windows of the buildings.

In Soceng ideology, Orthodoxy is the love for Big Brother. To ensure this, governmental institutions are created - the Ministry of Truth, the Ministry of Abundance, the Ministry of Peace and the Ministry of Love, which is responsible for the Thought Police. The Soceng doctrine is built within the Inner Party by diabolical minds and is based on the knowledge of human weaknesses and possible types of reaction when facing terror. The thorough plan to create, by any means, a climate of powerlessness and mistrust in values proves to be efficient. The policy of orderly amnesia, the leveling of personalities, the suppression of any trace of dignity have transformed people into grotesque, mechanically functioning beings, because thoughts and feelings are controlled, culture is abolished and the past is changed in official documents and in the common daily newspaper according to the Party's interests. This world has no chance of recovery, because the children are educated in the cult of lying and emulate their spirit according to the principles of the system: the daughter of the Parson family denounces her father to the Thought Police. Referring to the sick state of our society in the years of the Stalinist regime, Eugen Negrici makes a disturbing confession, which urges us to believe in the possibility of an overturned mimesis: "The Romanian scholars from the beginning of the 1950's (among whom I am myself) will be delivered the story of the pioneer Paul Morozov, murdered by the members of his own family because he had turned in his father" (Negrici 2002: 79). The few people who search for the origin or identity are locked in the Ministry of Love, scorned, healed and then killed.

\section{THE CRISIS OF THE INDIVIDUAL FACING TOTALITARIANISM}

In Nineteen Eighty-Four, George Orwell relied on the literary motive of the revolt against authority. What sets the boundary between ordinary and artistic in this novel is the unmistakable type of reaction of the individual, a kind of rebellion against the barbarianism of totalitarianism.

The main character, Winston Smith, defined by a reflective mind with access to philosophical references, faces a disgusting social system, with aberrant practices, based 
on an oppressive and yet cunning apparatus. The character is kept away from total engagement and sublime gestures, not letting himself become an unbridled enemy of the schizophrenic society in which he lives. George Orwell had a great dose of aesthetic courage, thematically speaking, and his character became emblematic for a certain type of revolt. With Winston Smith, the author offers us a destiny prone to failure, a plausible artistic hypostasis, showing us that nothing can be changed when people face the absurd, because men may seem helpless and the rebellion means suicide.

In this vision of the human environment as an irrational system of absurd antihuman powers, heroism and grandeur remain terms that cannot gain empirical content, as they have no chance of affirmation. Winston knows he is helpless, and the readers, following the movement of his soul, understand that lack of sincerity can also fit into what we suppose to be the essence of the human being.

Nineteen Eighty-Four is considered a very representative novel for its visionary boldness, opposing to the proletarian hypostasis of the heroes of the great literature. It depicts the tragic image of the vulnerable human being, who understands his limits. The author is not concerned with an abstract humanity, with the history of the species, but he firmly opposes the humble neglect of humanity. He takes the side of literature and is able to speak deeply about the complexity of history. Throughout the epic deployment, the human substance remains the same: the biography of a petty man, of the human being subjected to humility and pain. Winston Smith, an official of the Lower Party, reveals himself in all his fragility and weakness, a suffering man, terrified of rats, able to enjoy some prohibited food purchased by his beloved Julia.

The complexity of writing and the finesse in the dosing of allusions and symbolism are obvious features of this novel. Although it is a creation of anticipation, in which the real, the fantastic, the oniric, the intuition and the realistic observation are mixed, they remain equal throughout the novel. Concerned with symmetries and significant coincidences, the author inserts a decisive detail of a scene in the novel.

In a society marked by historical tragedy, helplessness and resignation, in a godforsaken world, Winston Smith questions the morality of freedom, not from the perspective of concepts, in the Sartrian style, but in a simple way, in an attempt to change the order of things in any way. His revolt does not materialize in a heroic decision, it is not the effect of an irrational and aggressive lucidity, nor does it remain an act in itself, as in Camus's L'homme révolté (1985), but coagulates slowly, uncertainly, without reaching the maximum intensity. In the conditions of life under an oppressive regime, in which the physical suppression of the individual is usual, rebellion, in any form of manifestation, is dangerous and, in any case, has no prospect of a liberating conclusion. Winston revolts, even if he does not reach towards a profound molecular change of life and expresses a lust for intense living in the name of a superior sense. His revolt has a dramatic evolution. He starts writing a diary which he keeps hidden, and then puts his hope in the proletarians of whom he thinks had never lost their humanity. He sees in them a force that could awake and bring life back to the natural course, but he will not try to approach them. Discovering, due to the negligence of an official, the technology of falsifying the past and the truth, he wants to get out of the state of resignation caused by the contemplation of the evil that surrounds him. Animated by a 
diffuse meliorism, he seeks a way of social engagement, not through the unconditional assumption of a heroic posture, but by engaging in an alleged organization of which he believes it conspires against the Party. Prudent, elusive, fearful, he goes with Julia to the person who will prepare his horrible end, $0^{\prime} B$ rien, the terrible oppressor, a member of the Inner Party and Thought Police, a doctrinal maker of Soceng, whom he naively suspects to be part of the plot.

The adherence he communicates to 0 'Brien has nothing exalting, but is disturbing by its veracity: it is the testimony of a tormented soul, a mixture of insecurity, fear, hope, revolt, which is equivalent to a sublime impotence, located at the boundary of cowardice. He is not looking for an ally in $0^{\prime} B$ rien, but rather for a protector:

- I came here because ...

He paused, realizing for the first time how vague the reasons were. Since he did not know what kind of help he was expecting from 0 'Brien, it was not easy to say why he had come. He continued, aware that the words sounded to him as unconvincing as to be pompous:

- We think there is a kind of conspiracy, a kind of secret organization that plots against the Party and in which you are involved. We want to join and work in it. We are enemies of the Party. We do not believe in the Soceng principles. We are criminals in thinking. We also make ourselves guilty of adultery. I tell you all this because we want to let you go. If you want to incriminate and do some other way, we are ready to do it. (Orwell 1991: 187)

In Orwell's novel there is an acute moral disagreement between the individual and the society. The author always supervises his character, disgusted with his own conformism and dehumanization. When the tension of self-deprecation goes beyond the barrier of a natural example, it reveals its tragic fright, for the unassailable aspiration to re-establish within the limits of normality a society bursting with evil does not lead to fulfillment, but calls for the ultimate sacrifice. By responding to $0^{\prime} B$ Bien that he is willing to commit suicide when and if he is ordered to do so, the character appears in his fatal naivety, in a desperate need for confidence.

The lack of hope seen in the twisted evolution of the destiny of the character disturbs the consciences decisively and transfiguratively, as do the figures of the great rebels of the great masterpieces of literature. Orwell's hero is not one of them, but he offers a tragic dignity to the conflict between the individual and the world, not by the greatness of the revolt, but by its affirmation.

\section{THE ROLE OF THE LANGUAGE IN CREATING SCIENCE FICTION PROSE}

In a dystopian novel of anticipation, which contains the topic of tragic subjectivity, crushed by the odious mechanism of a totalitarian state, Orwell puts us in front of an unbelievable image of the world, but the human truth it carries is undoubtedly verisimilous and can be received, understood and lived through reading. Although it is a virtual epic, transfiguring space, the observation of the human being is as convincing 
as it is in the objective literature. The author may be criticized for the validity of the vision of the world, but not for the solidity of it as an aesthetic object. Critics, especially the Impressionists, had in mind, in particular, the atmosphere created in the novel, the recognizable political practices, the original fiction and the ambiguity of the human experience.

What we gather at the first reading of the book is the complexity of the imaginary language that creates the impression of the most realistic fictional prose, crossed by a grim parabolism and a distinct symbolism. The novel conveys the sense of distress and, technically speaking, it is the consequence of introducing insolvency, of breaking the relationship between cause and effect.

The imaginary universe is the particular sign of this science fiction creation, even if it is limited to coexistence in the verosimile chain of the insoluble element. The formula of veracity meets the fantastic, both as hypostases of the aesthetic universe, which has as its only substance the human truth. This novel confirms the thesis of Marin Beșteliu's realism of fictional literature.

The attempt to define the fictional structure of Nineteen Eighty-Four is required by evidence and supported by detail. We can observe that, from the compositional point of view, the reader's hesitation (possibly by refusing the allegorical perception of the text) and the peculiarities of the style (modulation) can support the exigencies of the category of science fiction. Reducing its features to formal attributes by ignoring the authenticity of the human substance that the novel communicates is, however, out of analytical lucidity. At the ideatic level, the fictional expresses the most acute terror of the object-to-object relationship.

At the level of the narrative structure, the fictional confirms the genre of narrative, in which the realistic and the fictional images dispute the space of knowledge. The writing is infused with strange coincidences whose significance is related to semiotics. Umberto Eco's (1989: 53) comment on the tendency of the modern prose structure to include open work can be applied to Orwell's novel.

The ambiguity resulting from this complex piece of writing determines the author's open-mindedness in the process of narration. Coincidences are added to the identities of the dream images with the signs of horror and the degradation metronomies of the real order, symmetries of symbols, repeating allusions, obsessive memory flashes and ugly dream breaks. The most interesting thing in the book is the transfer of the fictional into the real. In the epic field, the distinction of the two domains cannot easily function. The impetus that we have of resuming reading to reconstruct the previously distributed sequences is the clue which shows us that we deal with a complex writing which is a successful demonstration of ambiguity. This results not only from the sliding of the science fiction into the realistic of the narrative construction, but also from the interference of the oniric in the real. We consider that characters are hesitant human beings, trying to find a balance between a natural explanation and a supernatural explanation of the evoked events. 


\section{ANTICIPATION AS A METHOD OF GENERATING AMBIGUITY AND TENSION}

The unusual in the novel triggers images of serious premonitions, anticipating dramatic events. The image of his mother sinking with his sister somewhere in an underground place - the bottom of a well, for example, or a very deep tomb, is repeated in nuance, terrorizing him while he is in a state of wakefulness. He sees himself compelled to confront the embarrassing fantasies of the past, his embarrassing hypostases, with cruel, punishing reality sequences. This nightmare becomes a way of recovering the traces of his sensibility and humanity, bringing painful memories back to life, which intensify his sense of guilt. The epic passage in which he takes away from his sick sister the chocolate ration that had been distributed by authorities is memorable because of its blunt realism. The mother's gesture to protect her baby by covering her with her arm still obsesses him and this gesture is yet repeatedly recognized thirty years later by the Jewish woman whom he had seen in the informative film trying to keep the little boy out before the helicopters took them both up into the air. The helpless mother's attempt to defend her little girl is the anticipation of an evil beyond forgiveness over which the hero begins to think and to perceive it differently from the way it appears on the front page of his diary: "April 4th, 1984. Went to cinema last night. Only war films. A very good film about a ship full of refugees bombed somewhere in the Mediterranean" (Orwell 1991: 206).

The tension of the character's experience in identifying the realm of the dream landscape, which he called the Golden Realm, is also communicated to us: "Winston looked out into the field beyond the forest and slowly felt a strange shock of recognition. He knew the spot from sight. An aged pasture, roughened to the ground, through which a bumpy path was streaming, with a tuft of horns here and there" (Orwell 1991: 231). The Prison without windows - The Ministry of Love, where Winston will be imprisoned and tortured is anticipated in dreams in the cynical form of a voice that seems to be 0'Brien's:

Years ago - how many? about seven, probably - dreamed that he was going through a darkened room. And someone sitting in a corner somewhere said to him as he passed: "We'll meet in the place where there is no darkness." This phrase had been uttered very softly, almost indifferent - as a statement, not as a commandment. He continued to walk without stopping. The strange part was that at that moment, in a dream, the words had not made it too strong. It was only later, and gradually, that they seemed to have a meaning. He no longer remembered whether he had first seen $0^{\prime} B$ rien before or after his dream, or when he had first identified his voice as $0^{\prime} B$ Bien's. In any case, however, this identification exists. $0^{\prime}$ Brien was the one who had turned from the darkness. (Orwell 1991: 261)

The certainty that starts to sink in, when 0'Brien utters at a meeting the same phrase as if he had recognized the allusion, is then projected into a wide field of indeterminations, the ambiguity being enhanced by negative aspects and modulation.

In the gestures, attitudes and expressions of the prisoners, the main character recognizes the objective correlatives in Elliot's language - of his permanent fear: 
Parson was taken. Then other prisoners came and vanished mysteriously. One of them, a woman, was sent to Room 101 and, as Winston remarked, she seemed to be twitching when hearing those words. Accumulating details of people's manifestations before being taken to Room 101 is a way of highlighting anxiety in the face of the unknown. The simple fact of announcing her number by the officers causes Winston a state of mind that can be compared to the numbness of the senses following a blow, when the full perception of reality is not yet possible, and things seem to express interferences that the human mind does not dominate. The terror intensifies, becoming almost paralyzing, preventing him from asking $0^{\prime} B$ Bien what was there:

He still had not asked the first question that had come in his mind. She had to ask it, yet the tongue seemed to refuse to speak. $0^{\prime}$ Brien's face had a trace of amusement. Even in his glasses was an ironic glint. He knows, Winston thought, he knows what I'm going to ask him! At this thought, the words gushed into him:

- What's in Room 101?

The expression on 0 'Brien's face did not change.

"You know what's in Room 101, Winston!" he said. "Everyone knows what is in Room 101." (Orwell 1991: 274).

The question is just an attempt to postpone the decisive moment of confronting the worst thing in the world that he knows he can not avoid. This, $0^{\prime}$ Brien explains, differs from individual to individual, and for him it happens to be rats. Terror would not have sought expressivity in the text if it had not been tense from within, in the scene in which Julia discovers a rat in the rented room in Charrington's shop:

For a few moments he felt that he had been in a nightmare he had sporadically. It was always the same. He stood in front of a wall of darkness and on the other side was something unbearable, something too horrible to be seen. In that dream, the strongest feeling was self-deception: the truth was that he knew what was beyond the wall of darkness. If he was making a colossal effort, as if he were pulling a piece of his brain, he could even bring that thing to light. He always woke up before discovering what it was. But it had something to do with what Julia said when he had interrupted so suddenly. (Orwell 1991: 296)

Winston's terror contains the germs of his own destruction. The methodical analysis of O'Brien's psychological abyss casts a sudden light on the meaning of selling dreams. The character cannot survive because he does not bear the principle of salvation in him. The hungry rats, ready to be released on Winston, who found himself tied to a chair, with his head trapped in a mechanism that forced him to look ahead, is $0^{\prime}$ Brien's final argument to cure him of heresy, clean his memory, feelings, humanity and his spirit, in order to love Big Brother. Under a type pressure he cannot resist, Winston betrays Julia - she is also incarcerated - demanding that her body be pushed between him and the rats. Cured, he walks to death, regretting the mistake of not having loved Big Brother for such a long time: 
He walked through the white tile corridor with the feeling that he was walking in the sunlight with an armed guard in his back. The much-wanted bullet penetrated the brain. He looked up at that enormous face. And it must have been forty years to find out what kind of smile he hid under the black mustache. What cruel and unnecessary misunderstanding! Oh, what a willing, spirited gesture from that loving chest! Two tears smelling of gin slid them to one side of the nose. But it was all right, everything was all right, the fight was over. He was loving Big Brother! (Orwell 1991: 305)

\section{CONCLUSION}

All things considered, Nineteen Eighty-Four is the fictional expression of human realism. Ambiguity defines this novel, even though the fictional intention develops as a realistic analysis of life. The author is deeply interested in the human personality. The strange happenings impress through their insolvency, as the events are out of the ordinary, cumulating everything that the cruel and destructive modern spirit could have ever imagined. The indecision and the uncertainty of perceiving the real are assimilated by us, readers, who integrate ourselves into the world of the novel, living the fictional as an aesthetic reality.

\section{REFERENCES}

Camus, A. 1985. L'homme révolté. Paris: Gallimard.

Compagnon, A. 2000. Il demone della teoria. Torino: Einaudi.

Eco, U. 1989. The Open Work. Cambridge: Harvard UP.

Grigore, R. 2016. George Orwell. The Dystopic Discourse and the Novel of the XXth Century.

Bucharest: Academia.

Huxley, A. 1932. Brave New World. London: Chatto \& Windus.

Negrici, E. 2002. Romanian Literature under Comunism. Bucharest: Editura Fundației PRO. Orwell, G. 1991. Nineteen Eighty-Four. London: Penguin Books.

\section{SUMMARY}

\section{AESTHETIC LEGITIMACY FOR THE DYSTOPIAN ENVIRONMENT IN ORWELL'S NINETEEN EIGHTY-FOUR}

George Orwell's Nineteen Eighty-Four (1949) contributed to the appearance of strong feelings of dislike against the type of oppressive, totalitarian regime, through the impact the novel had upon an enormous number of readers. The interest of the public in the image of the controlled individual by an almighty state remains high, even though Postmodernism, with its permissiveness, has generated the diversification of literary forms, technical inventions and, in the sense of reception, changes in taste 
and mentality. George Orwell imposed the most revealing description of a dystopian environment, surpassing the phenomenon of definitive human degradation under the assault of irrational cruelty. Orwell's fictional world has aesthetic legitimacy, even though there were critics that noticed the presence of a single narrative voice. The author created a parable developed with Kafkian means, an irrational fictional world, but, paradoxically, passionately read by the public for its cruel, revealing realism and memorable scenes. The novel fails to reach the aesthetic absolute, it does not illustrate a remarkable constructive performance, but confirms a major human problem and existential tension, creating the impression of thorough analysis of humanity. The difficulty of writing is the metaphor of the irrationality of the world and the book is a transparent product, through which we follow the mechanism of terror in full operation.

KEYWORDS: dystopian environment, mentality, human degradation, tension, mechanism of terror.

ARTICLE INFO:

Original scientific paper

Received: April 1, 2020

Revised: May 19, 2020

Accepted: May 27, 2020 